\title{
Case Analysis of Post-Placenta IUD Expulsion
}

\author{
Dewi Setyoningsih ${ }^{1}, *$ Evi Nurhidayati ${ }^{2}$ \\ ${ }^{1,2}$ Faculty of Health Science, 'Aisyiyah University of Yogyakarta, Indonesia \\ * corresponding author \\ Submission date: 10 Juli 2018, Receipt date: 10 Oktober 2019, Publication date: 1 Juli 2020
}

\begin{abstract}
Indonesian Government has launched various programs to overcome population problems. Postpartum Family planning program is included in maternal insurance program, so every partum mother can immediately insert Post-placenta IUD for free. The failure of inserting IUD contraception in Indonesia reached 37.75\%. The result of this review can be taken into consideration regarding goverment policy about Postpartum Family Planing Programe. The design of this study is literature review. The selected articles are those relating to IUD Post-placenta expulsion. Database PubMed used to cellecting article. We only take article that published from $2010-$ 2018. The analysis of 11 journals showed that the IUD post-placenta have rates of expulsion varies from some article, the lowest $1,4 \%$ and highest $24 \%$. Then delayed insertion of IUD have expulsion rates $0 \%$ up to 37\%. This review supports the evidence that insertion of an IUD Postplacenta after vaginal delivery or caesarean delivery is safe. Expulsion rates should be further studied in larger randomised controlled trials.
\end{abstract}

Keywords: IUD Post-placenta, Immediate IUD insertion, Expulsion, Expelled

\section{INTRODUCTION}

Indonesian Government has launched various programs to overcome population problems. One of the programs is National Family Planning which aims to realize population-oriented development and realize small, happy, and prosperous family. Effective contraception after delivery helps to keep pregnancy spaced and also improves health for both mother and baby. Prolonged birth spacing also reduces the risk of maternal complications such as bleeding in the third trimester, puerperal endometriosis, anemia and even death (WHO, 2005). To reduce the health risks of mothers and children the World Health Organization recommends delaying 24 months after delivery before the next pregnancy. Inserting Post-placenta IUD has disadvantage; one complication of IUD use is the occurrence of expulsion. Time and method of insertion well as the ability of staff (doctor and midwife) have an effect on the success of IUD installation. The occurrences of IUD post-placental expulsion happens because the installation is done when the condition of the uterus is still large, so the IUD can be pushed out in line with the process of restoration of uterine size to its original form. This incidence of expulsion is estimated $11 \%$. This means, from 100 people who use post placenta IUD there are 11 people who have IUD expulsion. Expulsion is more commonly found in the first 3 months after insertion (Paula et al, 2011). Clinical Demographic Survey of BKKBN stated that the failure rate of IUD contraceptives in Indonesia reached $37.75 \%$ or 57 cases from 151 cases of failure. Meanwhile, when viewed from the failure rate in the 
Java-Bali region, the result is still high at $44.19 \%$. (BKKBN, 2008). The Ministry of Health launched the Jampersal Program (Maternal Health Insurance) in 2015. The participants of the program are pregnant women, partum, postpartum (postpartum to 42 days) and newborn babies (0-28 days) who do not have health insurance coverage (Juknis Jampersal, 2011). Postpartum family planning program is united together with delivery program so that every mother who participate in this program can be the participant of family planning program or can directly insert contraceptive device right after the partum process (Health Ministry, 2013). Data by Yogyakarta Health Office (2013) stated that the percentage of postpartum contraceptive service showed the highest in Bantul (57.2\%), Kulonprogo (49.2\%), Kota Yogyakarta (43.1\%), Sleman (42.9\%), and the lowest in Gunung Kidul (32.3\%). We conducted this review as the consideration for government policy regarding Postpartum Family Planing Programe (IUD Postplacental).

\section{RESEARCH METHODS}

The design of this study is literature review. The selected articles are those relating to IUD Post-placenta expulsion. While the specified exclusion criteria are articles published more than 10 years and review article. The measured outcome is the number of expulsion incidents. The implementing process of the review literature was by collecting articles using database PubMed to browse articles related to IUD Postplacenta and expulsion incidents, with keywords of IUD Post-placenta, Immediate insertion of IUD and Expulsion or Expelled. While the selected Boolean operator is "OR" plus "AND" to expand the search area.

We only choose article using English language, and Eleven article that included in this studi is published from 2010 - 2018. The format of the article should be in full text and all the articles were unpaid/free downloaded articles. The study applied quality of the article using SCImago Journal Rank. Ethics approval was not sought as our research did not involved human subjects. We included articles that compared different time periods or routes (vaginal delivery vs at caesarean section) of IUD insertion in the postpartum period. we excluded articles that examine IUD insertion post-abortion and IUD insertion after uterine aspiration.

Our search yielded 2992 articles. Then we limit 10 years and choose only clinical trial and clinical studi full text eligibility we get 56 article. After reviewing the titles and abstracts as well as the full text articles when necessary, we included a total of 11 studies.

The next process was analysis all the articles. The data that we take from the article for the analaysis are about the who is the author, when this study done (year), who become the participants of this studi (repondent), how many sample included in this study (sample size), comparison (some articles compared different time insertion and routes vaginal delivery vs at caesarean section), expulsion rates (what precentage of expulsion occur) and the time of expulsion (when the expulsion occur). 
After collecting the data, the next step was the synthesis of data or combining the parts or elemets so as to form a whole that would be connected, we make the analysis in the table so it will be easy to read and understand. Then we make the review of Postplacental IUD expulsion incidents from the eleven article that was used in this studi.

2992 records identified through database searching

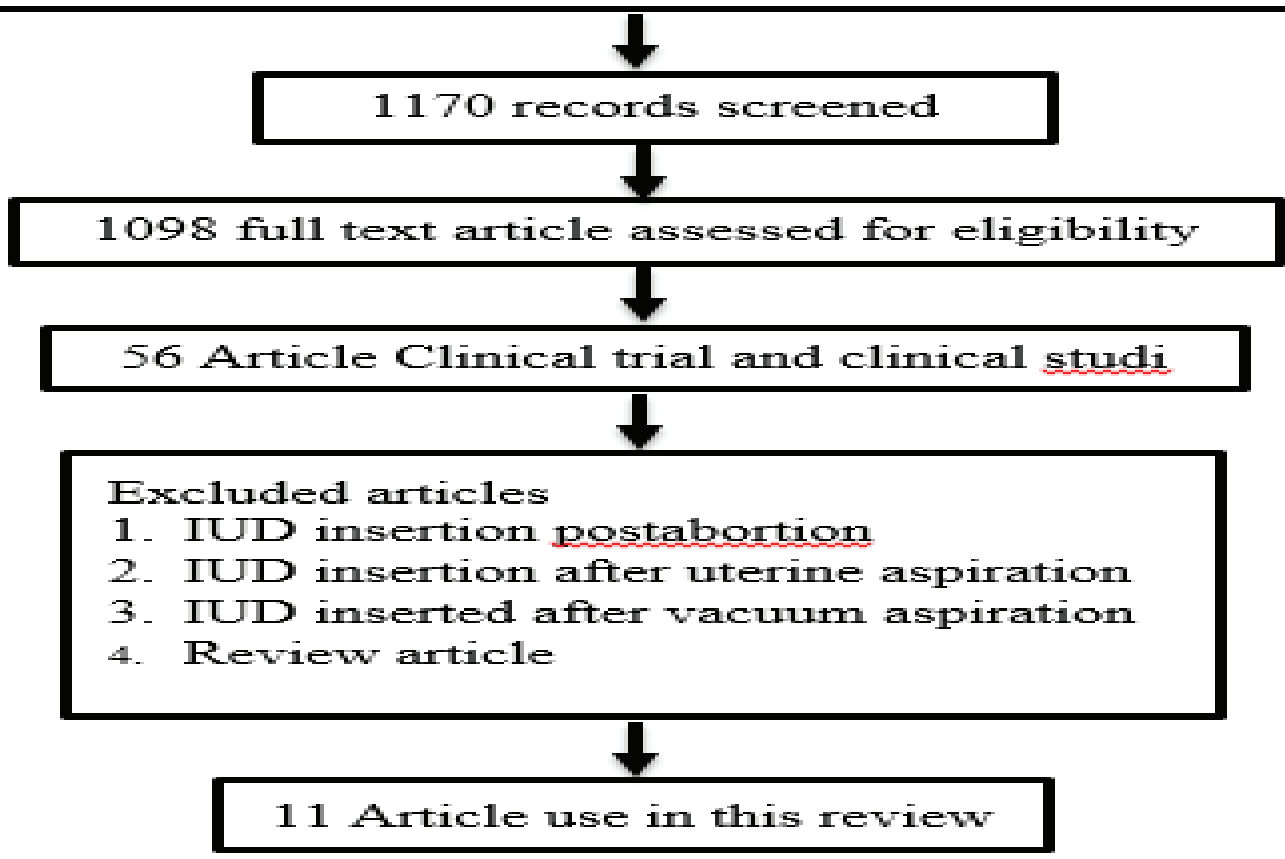

Figure 1. Diagram search and selection strategy of relevant paper

\section{RESULTS AND DISCUSSION}

Eleven article met the inclusion criteria, all the subject were postpartum women, some of the articles compare beetween IUD insertion after vaginal delivery and caesarean section delivey. The result show that the expulsion rate when it inserted after vaginal delivery are $4 \%$ up tp $8,99 \%$ then the IUD insertion after caesarean delivery are $2 \%$ up to $8,9 \%$ in the six up to twelve month follow up. The other one compare between insertion IUD Nova T380, Multiload 375 and Cooper T 380A and the result are $13 \%$ the expulsion rates of Nova T380, $5 \%$ expulsion in Multiload 375 and $15 \%$ the expulsion rates of Cooper T380A it happen after 12 month follow up . Beside that there is article that compare IUD Postplacenta that inserted before 10 minutes after delivery and Early postpartum insertion after 10 minutes until 48 hours after birth. The average expulsion rates in IUD Postplacenta is $1,4 \%$ up to $24 \%$ then IUD insertion in 48 hours is $0 \%$ up to $37 \%$. The next article is compared IUD type TCu 380A and IUD GyneFix. The result show the expulsion rate $11,40 \%$ occur in the participant who using IUD Tcu $380 \mathrm{~A}$, it is higher than IUD type GyneFix that only 1,4\% after 6 weeks up to 3 month follow up.

In general studies excluded women with intrapartum infection and other contradiction to IUD insertion. The timing of the evaluation of the expulsion varies, starting 7 days up to 12 month (1 year). 
The article that used in this study are from several different country such as America, Belgia, India, Nigeria, Pennsylavania and Egypt. All of them have different result about IUD postplacental expulsion rates. The highest expulsion rates was $24 \%$ it found from the article Beatrice (2010) in Magee hospital of Pittsburgh than the lowest expulsion rates was $1,4 \%$ in the article of Unal Ceren (2018) from Belgia.

Postplacental IUD insertion is defined as insertion within 10 minutes after delivery of the placenta. The identified studies compare posplacental IUD insertion with insertion at other time periods, or compared postplacental insertion after vaginal delivery versus at caesarean section. The result show that the expulsion rates of IUD Postplacenta was vary from the several article.

Here it is Health Technology Assesment (HTA) analysis in contraceptive use of Post-placental IUD when compared to other contraceptives such as condoms, pills, injections, etc. IUD contraceptives are calculated to have high cost benefits. Because once the average installation of IDR 600,000, it is effective up to 3 - 10 years depending on the type of IUD. The review of the 11 journals performed participants has a characteristic average age of 13-45 years. Incidence of IUD expulsion increases in women $<20$ years of age. IUD insertion in $>10$ mnit-72 hours also has a high enough expulsion rate compared to IUD installation after 4-8 weeks postpartum. Post-placental IUD Expulsion is most common in the first year of installation.

Postpartum placement of an IUD, especially within 48 hours is adventageous for the women as it provides reliable, effective contraception at the point of care. In addition motivation for effective contraception may be high after delivery. Most of the study show that expulsion rates within one year are lower for IUDs placed at the time of caesarean section.

Table 1. Journal Analysis Result

\begin{tabular}{|c|c|c|c|c|c|}
\hline Author (years) & Sample & $\mathbf{n}$ & Comparison & $\begin{array}{c}\text { Expulsion } \\
\%\end{array}$ & $\begin{array}{c}\text { Time of } \\
\text { expulsion }\end{array}$ \\
\hline Mishra S (2014) & $\begin{array}{l}\text { Postpartum } \\
\text { women }\end{array}$ & 564 & $\begin{array}{l}\text { Post- Placental } \\
\text { Intra Caesarean } \\
\end{array}$ & 8,99 & $\begin{array}{c}\text { Between } 7 \text { days } \\
\text { up to } 4 \text { weeks }\end{array}$ \\
\hline Amy Whitaker (2013) & $\begin{array}{l}\text { Postpartum } \\
\text { women }\end{array}$ & 42 & $\begin{array}{l}\text { Post-Placental } \\
\text { Delayed }\end{array}$ & $\begin{array}{c}20 \\
0\end{array}$ & 12 month \\
\hline Unal ceren et al (2018) & $\begin{array}{l}\text { Postpartum } \\
\text { women }\end{array}$ & $\begin{array}{c}106 \\
34 \\
\end{array}$ & $\begin{array}{l}\text { Tcu 380A } \\
\text { Gyn-CS }\end{array}$ & $\begin{array}{c}11,40 \\
1,4 \\
\end{array}$ & $\begin{array}{l}\text { After } 6 \text { weeks up } \\
\text { to } 3 \text { month }\end{array}$ \\
\hline Sucak ayhan (2015) & $\begin{array}{l}\text { Postpartum } \\
\text { women }\end{array}$ & $\begin{array}{l}47 \\
62\end{array}$ & $\begin{array}{l}\begin{array}{l}\text { Elective caesarean } \\
\text { delivery }\end{array} \\
\begin{array}{l}\text { Emergency } \\
\text { caesarean delivery }\end{array} \\
\text { Vaginal delivery }\end{array}$ & $\begin{array}{l}8,9 \\
11,3\end{array}$ & 12 month \\
\hline Halder Abhijit (2014) & $\begin{array}{l}\text { Postpartum } \\
\text { women }\end{array}$ & $\frac{100}{100}$ & $\begin{array}{l}\text { Delivered vaginally } \\
\text { Underwent } \\
\text { cesarean }\end{array}$ & 2 & 12 month \\
\hline Guie PY et al (2016) & $\begin{array}{l}\text { Postpartum } \\
\text { women }\end{array}$ & 790 & - & 1,5 & $\begin{array}{l}\text { After } 6 \text { weeks up } \\
\text { to } 3 \text { month }\end{array}$ \\
\hline $\begin{array}{l}\text { Beatrice A. Chen et al } \\
\text { (2010) }\end{array}$ & $\begin{array}{l}\text { Postpartum } \\
\text { women }\end{array}$ & $\begin{array}{l}51 \\
51\end{array}$ & $\begin{array}{l}\text { Postplacental } \\
\text { Delayed }\end{array}$ & $\begin{array}{l}24 \\
4,4\end{array}$ & 6 month \\
\hline Shukla Manju (2012) & $\begin{array}{l}\text { Postpartum } \\
\text { women }\end{array}$ & 1037 & $\begin{array}{l}\text { Immediate post- } \\
\text { placental } \\
\begin{array}{l}24 \text { to } 48 \mathrm{~h} \text { after } \\
\text { delivery }\end{array}\end{array}$ & 37 & 6 month \\
\hline $\begin{array}{l}\text { George IE Eluwa et al } \\
(2016)\end{array}$ & $\begin{array}{c}\text { Postpartum } \\
\text { women }\end{array}$ & 728 & - & 8 & $<6$ week \\
\hline
\end{tabular}




\begin{tabular}{|c|c|c|c|c|c|}
\hline \multirow{2}{*}{ Blumenthal et al (2016) } & \multirow{2}{*}{$\begin{array}{l}\text { Postpartum } \\
\text { women }\end{array}$} & 74 & $\begin{array}{l}\text { Post-placental } \\
\text { insertion }\end{array}$ & 10,8 & \multirow{2}{*}{$6-12$ month } \\
\hline & & 217 & $\begin{array}{l}\text { Within } 48 \mathrm{~h} \\
\text { insertion }\end{array}$ & 4,1 & \\
\hline \multirow{3}{*}{ Ragab A et al. (2015) } & \multirow{3}{*}{$\begin{array}{c}\text { Postpartum } \\
\text { women }\end{array}$} & 40 & Nova T380 & 13 & \multirow{3}{*}{1 year } \\
\hline & & 40 & Multiload 375 & 5 & \\
\hline & & 40 & Cooper T380A & 15 & \\
\hline
\end{tabular}

Insertion of an intrauterine device (IUD) immediately after delivery is appealing for several reasons. A number of large studies have noted that IUD insertion is relatively easy pain fee, easy insertion, easy access and the convenience for both the women and the service povider. the woman is known not to be pregnant, and her motivation for contraception may be high. For women with limited access to medical care, the delivery affords a unique opportunity to address the need for contraception. Service provider skills and experience are important factors for a success contraceptive, the lack of skill and experiences can cause perforation in IUD insertion, beside that the importance of insertors skills in immediate postplacental IUD related in reducing the expulsion rates.

IUD as the long acting reversible contraceptive (LARC) it helping women to space out and adequately nourish their children, especially in the developed countries as Indonesia. So it can increase maternal and child health status. So far no consistent pattern have been detected in expulsion rates but multiple studies of postplacental IUD insertion seggest that this timing of insertion is safe. Inserting an IUD at the time of caesarean section is a very attractive option. It adds very little time and cost to the procedure. The patient doesn not have to come back especially for follow up, and there is no risk of primary perforation (secondary perforation is possible).

Generally, researchers agree that the benefits of IUD use far exceed the associated riski and that IUDs have a number of relative adventages when compared with other contraceptive methods. Overall, immediate post-partum insertion of IUDs appears safe and effective.

\section{CONCLUSION}

Expulsion rates were higher for IUDs placed between 48 hours after delivery as compared to those inserted before 10 minutes and four week postpartum or at times unrelated to delivery. Insertion at the time of caesarean section is associated with lower expulsion when compared to postplacental vaginal insertion. Many of the included studies identified other potential confounders for higher rate expulsion such as age, parity, and provider inexperience, one study demonstrated differences in expulsion rates between primiparous and grand multiparous women. IUDs are long-term contraceptives that are suitable for use by women who don't want to get pregnant. IUD contraception has a working period of 3-10 years.

Women should be counselled concerning differences in expulsion rates depending on the timing of postpartum IUD placement, ideally as part of contraceptive counselling during the antenatal period. Women given the convenience of timing, may prefer postplacental IUD placement. As expulsion rates are increased after postpartum 
insertion, follow up and counselling women on the sign expulsion of the device may assist in identifying and replacing those that are displaced. Provider training and infrastructure development may improve the ability to offer IUD insertion during this period

\section{REFERENCES}

Ahmed Ragab et al. 2015. Expulsion of Nova-T380, Multiload 375, and Cooper T380A contraceptive device inserted during caesarean delivery. International Journal of Gynecology and Obstetrics. http:/dx.doi.org/10.1016/j.ijgo.2015.03.025

Amy K Whitaker et al. 2013. Postplacental insertion of the levonorgestrel intrauterine device after cesarean delivery vs delayed insertion: a randomized controlled trial. Universitas Chichago Medical Center di Amerika Serikat. DOI: 10.1016/j.contraception.2013.12.007

Beatrice A. Chen et al. 2010. Postplacental or Delayed Insertion of the Levonorgestrel Intrauterine Device After Vaginal Delivery. Department of Obstetrics, Gynecology, and Reproductive Sciences, University of Pittsburgh. doi:10.1097/AOG.0b013e3181f73fac.

BKKBN. 2008. Kajian Implementasi Kebijakan Penggunaan Kontrasepsi IUD. Badan Kependudukan dan Keluarga Berencana Nasional

Ceren Unal et al. 2018. Comparison of expulsions following intracesarean placement of an innovative frameless copper-releasing IUD (Gyn-CS $\left.{ }^{\circledR}\right)$ versus the TCu380A: $A$ randomized trial. Zeynep Kamil Women's and Children's Disease Training and Research Hospital, Ghent, Belgium. doi:10.1016/j.contraception.2018.03.034

George IE Eluwa et al. 2016. Success Providing Postpartum Intrauterine Devices in Private-Sector Health Care Facilities in Nigeria: Factors Associated With Uptake. Global Health Science and Practice. http://dx.doi.org/ 10.9745/GHSPD-16-00072

Halder Abhijit et al. 2014. A Prospective Study to Evaluate Vaginal Insertion and IntraCesarean Insertion of Post-Partum Intrauterine Contraceptive Device. The Journal of Obstetrics and Gynecology of India. DOI 10.1007/s13224-014-06402

JNPK-KR. Kementrian Kesehatan Republik Indonesia. 2011. Pelatihan Klinik Teknologi Kontrasepsi Terkini (Contraception Technology Update). BKKBN

Manju Shukla et al. 2012. Post-placental intrauterine device insertion- A five year experience at a tertiary care centre in north India. The Indian Journal of Medical Research. PMCID: PMC3510889

Paul D. Blumenthal. 2016. Programmatic experience of post-partum IUD use in Zambia: an observational study on continuation and satisfaction. The European Journal of Contraception \& Reproductive Health Care. http://dx.doi.org/10.1080/13625187.2016.1201655

Privat Yere Guie. 2016. Immediate postpartum insertion of intrauterine devices: experience of maternity ward of the university and teaching hospital of Treichville, Abidjan. International Journal of Reproduction, Contraception, Obstetrics and Gynecology. DOI: http://dx.doi.org/10.18203/2320-1770

Sucak, Ayhan, Sarp O., Sevki, C. et all. 2015. Immediate Postplacental Insertion of a Copper Intrauterine Device. A Pilot Studi to Evaluate Expulsion Rate by Mode of Delivery. BMC Pregnancy and Childbirth 2015. 
Sujnanendra Mishra et al. 2014. Evaluation of Safety, Efficacy, and Expulsion of PostPlacental and Intra-Cesarean Insertion of Intrauterine Contraceptive Devices (PPIUCD). The Journal of Obstetrics and Gynecology of India. DOI $10.1007 / \mathrm{s} 13224-014-0550-3$ 